\title{
Food consumption pattern and obesity in preschool children in Feira de
}

\section{Santana, Bahia, Brazil}

\section{Padrão de consumo alimentar e obesidade}

em pré-escolares, Feira de

Santana, Bahia

Karina Emanuella Peixoto de Souza GOMES ${ }^{1}$

Maria Conceição Oliveira COSTA ${ }^{1}$

Tatiana de Oliveira VIEIRA ${ }^{1}$

Sheila Maria Alvim MATOS²

Graciete Oliveira VIEIRA ${ }^{1}$

\section{A B S T R A C T}

\section{Objective}

To evaluate the association between food consumption patterns and obesity in preschool children in Feira de Santana, Bahia, Brazil.

\section{Methods}

Cross-sectional, population-based nested within a live-birth cohort study of 813 children, which has started in 2004 in Feira de Santana, Bahia. The anthropometric status among children under four years of age was evaluated based on their body mass index; obesity/severe obesity was defined as a Z-score $>+2$. The Food Frequency Questionnaire was used to identify dietary patterns using principal components analysis. The association between obesity and food consumption patterns was assessed using Pearson's Chi-squared test and logistic regression, adopting $p<0.05$ to denote statistical significance.

\section{Results}

Obesity was detected in $12.7 \%$ of the children investigated. Four food consumption patterns were identified: dietary pattern 1 (milk and other dairy products, vegetables and tubers, cereals, legumes, fruits, and fish); dietary

\footnotetext{
1 Universidade Estadual de Feira de Santana, Departamento de Saúde, Programa de Pós-Graduação em Saúde Coletiva. Av. Transnordestina, s/n., Centro de Pós-Graduação em Saúde Coletiva. Av. dos Laboratórios, Módulo 6, Novo Horizonte, 44036-900, Feira de Santana, BA, Brasil. Correspondência para/Correspondence to: KEPS GOMES. E-mail: <souzakep@gmail.com>.

2 Universidade Federal da Bahia, Instituto de Saúde Coletiva, Programa de Pós-Graduação em Saúde Coletiva. Salvador, BA, Brasil.

Article based on the master's thesis of KEPS GOMES entitled "Fatores associados à obesidade e o padrão de consumo alimentar de pré-escolares em Feira de Santana - Bahia". Universidade Estadual de Feira de Santana; 2011.
} 
pattern 2 (deep-fried or baked snacks, soft drinks/artificial fruit juices, oils and fats, sweets, and coffee/tea); dietary pattern 3 (encased meats, fast food, ketchup/mayonnaise, and eggs); and, dietary pattern 4 (chicken and red meats). Obesity was statistically associated with high adherence to the dietary pattern 3 (OR=1.92; $95 \% \mathrm{Cl}=1.01-3.66)$.

\section{Conclusion}

The results obtained showed that the high intake of energy-dense foods (dietary pattern 3) was a contributing factor to childhood obesity. These data reinforce the need for public policies and food education programs in health units and schools, aiming to change children's eating habits, significant predictors of nutritional problems.

Keywords: Child, preschool. Factor analysis, statistical. Feeding behavior. Obesity.

\section{RE S U M O}

\section{Objetivo}

Avaliar a associação entre padrões de consumo alimentar e a obesidade de pré-escolares em Feira de Santana, Bahia.

\section{Métodos}

Análise transversal de 813 crianças de uma coorte de nascidos vivos de base populacional, iniciada em 2004 em Feira de Santana, Bahia. O estado antropométrico entre menores de quatro anos foi avaliado por meio do cálculo do índice de massa corporal, sendo a obesidade/obesidade grave definida em escore $Z(>+2)$. 0 Questionário de Frequência Alimentar foi o instrumento utilizado para identificar os padrões alimentares por meio da análise fatorial de componentes principais. A associação entre a obesidade e os padrões de consumo alimentar foi avaliada mediante teste Qui-quadrado de Pearson e da regressão logística, tomando-se como critério de associação, valor de $p<0,05$.

\section{Resultados}

A obesidade para idade foi observada em 12,7\% das crianças estudadas. Foram identificados quatro padrões alimentares: padrão alimentar 1 (leite e derivados, verduras e tubérculos, cereais, leguminosas, frutas e pescados); padrão alimentar 2 (salgadinhos, refrigerante/sucos artificiais, óleos e gorduras, doces e café/chá); padrão alimentar 3 (embutidos, fast-food, catchup/maionese e ovos); e, padrão alimentar 4 (frango e carnes vermelhas). A obesidade mostrou-se estatisticamente associada à alta adesão ao padrão alimentar $3(O R=1,92$; IC95\%=1,01-3,66).

\section{Conclusão}

Os resultados da pesquisa mostraram que a elevada ingestão de alimentos altamente energéticos (padrão alimentar 3) foi fator contributivo para a ocorrência da obesidade na infância. Estes dados reforçam a necessidade de políticas públicas e programas de educação alimentar, nas unidades de saúde e escolas, para mudança dos hábitos alimentares das crianças, importante preditor de problemas nutricionais.

Palavras-chave: Pré-escolar. Análise fatorial. Comportamento alimentar. Obesidade.

\section{NTRODUCTION}

Obesity is considered a global epidemic. The risk of an obese child becoming an obese adult increases from $25 \%$ when this condition occurs during the first six years of life to $75 \%$ when it occurs during adolescence [1]. Genetic and environmental determinants are involved in obesity genesis. Eating habits is a major environmental factor contributing to obsesity $[2,3]$.
Nutritional status assessments of individuals and populations often include anthropometric measurements (direct method), food consumption questionnaires(indirectmethod), and demographic, socioeconomic, and cultural factors [4]. However, recently, frequency of food consumption has been used to identify dietary patterns using Principal Component Analysis (PCA) as an alternative to studies that include the isolated assessment of food/nutrient consumption $[5,6]$. 
According to the World Health Organization (WHO), the identification of dietary patterns of a given population, i.e., the variety of foods consumed by this population [7], is considered a more reliable method than nutrient consumption [8] since it represents the profile of food and nutrient intake, based on their usual intake [9].

The determination of the anthropometric profile and the food consumption pattern of a population is an important public health strategy that can contribute to therapeutic and educational actions, such as changing eating habits and increasing physical activities. The aim is to reduce the risk of morbidity due to nutritionrelated diseases. This study aimed to evaluate the association between food consumption patterns and anthropometric status of preschool children in Feira de Santana (BA), Brazil.

\section{METHO D S}

This is a cross-sectional, populationbased study nested within a live-birth cohort study carried out between April 2004 and March 2005 in the city of Feira de Santana (BA), whose objective was to evaluate the effects of breastfeeding, complementary feeding, and weaning on eating habits, growth, and health of children under six years of age.

The cohort consisted of a representative sample of live births (Feira de Santana residents) that were being treated in local hospitals. Live births were added to the cohort sample over the period of 12 months; two new hospitals were included every two months using the lottery method, except for two maternity wards that were included because they provided care to a greater number of women. In the present study, a total of 813 children younger than 4 years of age, who were followed-up in the cohort study were evaluated. More details on the cohort can be obtained in other publications $[10,11]$.

Data were collected during home visits using direct interviews conducted by health professionals working in pairs and properly trained university students. The interview questions were concerned with maternal and child characteristics, and they were clear and objective and offered multiple-choice answers.

Food consumption was assessed using a Food Frequency Questionnaire (FFQ) concerning food consumption during the child's fourth year of life. It was administered to the children's mothers or guardians. The FFQ was composed of a list of 133 foods and options for reporting the frequency of intake including the following frequency categories: never/rarely; 1-3 times per month; 1 time per week; 2-4 times per week; 1 time per day; and 2 or more times per day. Food frequency data were transformed into daily servings in order to use only one unit of time. Thus, average intake frequency was calculated for each food by dividing the weekly consumption by seven or monthly consumption by thirty.

Children's body weight and height measurements were obtained using a digital scale with a maximum capacity of $150 \mathrm{~kg}$ and an accuracy of $100 \mathrm{~g}$ and a portable, folding stadiometer capable of measurements up to 2.16 meters and capable accuracy of $0.1 \mathrm{~cm}$. All measurements were made in triplicate, and the reference value used was the arithmetic mean of the triplicate results.

Obesity was classified based on the anthropometric status evaluated by the direct method, that is, by calculating the BMI-for-age, according to WHO [12] reference curves. The Anthro [13] software was used, adopting the Z-score cutoff point $>+2$, which includes obesity and severe obesity.

The children characteristics evaluated were: gender, birth weight $(<2.500 \mathrm{~g}, \geq 2.500 \mathrm{~g})$, interruption of exclusive breastfeeding at 4 months, weaning at 2 years of age, bottle feeding, sleep feeding, and consumption of foods in liquid form. The maternal variables were: gestational age (preterm, full term), maternal age at childbirth ( $<20$ years, $\geq 20$ years), maternal 
skin color (white, black/brown), maternal level of education (incomplete elementary and middle school, high school/higher education), work outside the home, income $(\leq 1$ minimum wage, over the minimum wage), and maternal overweight/obesity.

The foods included in the FFQ were grouped using factor analysis. Thus, Food frequency data were transformed into a daily servings of each food and grouped into 17 food groups, based on nutritional characteristics and correlations obtained in the preliminary factor analysis. The following food groups were formed: group 1: milk and other dairy products (whole milk, skimmed milk, fermented milk, natural yogurt, petit suisse cheese, queijo prato (a Brazilian soft yellow cheese), mozzarella, queijo minas (a type of cheese produced in the Brazilian state of Minas Gerais), requeijão (a loose, ricotta-like cheese), porridge, smoothies (milk + fruit + chocolate milk powder mix; milk + chocolate milk powder mix; and milk + fresh fruits); group 2: ketchup/mayonnaise (mayonnaise, potato salad with mayonnaise, ketchup); group 3: encased meats (sausage and frankfurter sausage); group 4: fast foods (French fries, acarajé (a dish made from peeled beans formed into a ball and then deep-fried in palm oil), cheeseburger, sandwiches, coxinha de galinha (popular Brazilian food made with shredded chicken meat, covered in dough, battered and fried), cheese bread (traditional baked cheese roll), sfiha (meat pie [open-face or not], pizza, hot dogs); group 5: red meats - cooked meat, liver, fried steak, cooked lamb, fried lamb chops, pork, maniçoba (typical Brazilian dish made with leaves of the cassava plant and salted pork, dried meat, and smoked ingredients, such as bacon and sausage), sarapatel (a Portuguese dish made with offal and meats such as pork, lamb, or even beef), mocofato (traditional rich Brazilian dish made with beef [cow's feet], sausages, and bacon), rabada (a typical dish made with oxtail), buchada (Brazilian dish made with goat offal an bacon), and feijoada (a stew of beans with pork meat); group 6: vegetables and tubers - mashed potatoes, sweet potatoes, cooked yams, yams, lettuce, Chinese cabbage, pumpkin, watercress, cauliflower, beetroot, carrot, spinach, cucumber, tomato, vegetable soup, unstuffed or stuffed beiju (a typical dish made with tapioca), and flour; group 7: cereals - rice, noodles, instant noodles, pasta and pastries, cookies and crackers, French bread, breakfast cereal, couscous, corn, plain cake, popcorn, canjica (Southern Brazil) and/ or mungunzá (Northern Brazil) - sweet dishes or porridge made with white de-germed whole maize kernels (canjica), cooked with milk, sugar and cinnamon until tender; group 8: legumes (peanuts, beans, green beans, soybeans, bean soup), abará (typical dish of Bahia state based on a paste made from mashed black-eyed peas wrapped into pancakes inside banana leaves and steamed); group 9: fruits - pineapple, avocado, banana prata (burro or chunky banana), banana da terra (plaintain or cooking banana), guava, orange, apple, papaya, melon, mango, strawberry, sugar apple, grape, sugarsweetened fruit juice; Group 10: eggs (fried egg and quail egg); group 11: chicken (cooked chicken); group 12: fish (fried fish, shellfish, crab, and other foods used to prepare fish, especially coconut milk); group 13: packaged snacks (potato chips); group 14: soft drinks/ artificial fruit juices (traditional soft drink, diet soft drink, artificial juices, artificial beverages); group 15: sweets (chocolate, ice cream, freeze pop, chocolate milk powder mix, candies, fruit preserves, desserts, jello, pudding, sugar); group 16: oils and fats (margarine, butter, olive oil, palm oil, vegetable oil); group 17: coffee/tea. Some foods were excluded from the analysis because their reported consumption among the participants was less than 5\% (non-fat yogurt, pea soup, unsweetened juice, sweetener, natural or veggie sandwich, alcoholic beverages).

The daily servings from each food were grouped into a single value for each child by the sum of the servings of the foods from each food group. Therefore, it was possible to obtain a continuous variable that was standardized, according to Z-score of the standard normal 
curve. It is the input variable in the principal component analysis used to identify the dietary patterns.

The dietary patterns were identified by exploratory factor analysis using PCA. Principal Component Analysis is a multivariate statistical analysis, which allows the combination of variables based on the degree (strength) of the relationship between them. Thus, the variables grouped in each factor are strongly correlated with each other $[14,15]$.

Initially, the suitability of the sample for the application of for PCA was verified using the Kaiser-Meyer-Olkin test and the Bartlett's sphericity. Orthogonal rotation (Varimax) was used to determine the dietary patterns; this method provides nearly uncorrelated, distinct factors, improving the interpretability of the factor loadings.

The multivariate statistical approach of the exploratory factor analysis allowed the grouping of the food items in the FFQ according to the degree (strength) of correlation between them. The Kaiser's eigenvalue-greater-thanone rule and the Cattel's scree test were used to determine the number of factors to retain in the factor analysis. The foods or food groups that contributed to the characterization of each dietary pattern had factor loading $\geq 0.30$, considering the highest saturation factor, significance level of 0.05 , and power of $80 \%$, as recommended by Hair Jr. et al. [15]. The dietary patterns obtained based on the PCA were categorized into tertiles of the individual consumption scores of these dietary patterns and were denominated as follows: 1st tertile (low adhesion to the dietary patterns), 2nd tertile (moderate adhesion to the dietary patterns), and 3rd tertile (high adhesion to the dietary patterns).

To evaluate the association between obesity and dietary pattern, four logistic regression models were constructed because each dietary patterns identified was considered a main independent variable.
Statistical analysis was carried out using the Software Statistical Package for Social Science (SPSS, Inc., Chicago, Illinois, United States) 9.0 version [16] for Windows and validated using the EpiData software (Atlanta, Georgia, United States) program. The $\mathrm{R}$ programming language [17] was also used in the data analysis. Initially, the frequencies of the child and maternal characteristics and the frequency of children's anthropometric status were calculated. In the bivariate analysis, the prevalence, Prevalence Ratio (PR), and their respective confidence intervals were calculated to determine the factors associated with obesity, considering 95\% confidence interval as the threshold for statistical significance, according to the Chi-squared test.

In the bivariate analyses, the value of $p \leq 0.25$ was used for the inclusion of variables in the logistic regression model. To select the predictor variables that should remain in the model, variables with a $p-\leq 0.20$, obtained using the likelihood ratio test, were considered as candidate variables. A backward selection process and $p$-value $\leq 0.05$ (statistically significant associations) criterion were used to select the variables in the final model.

The present study was approved by the Research Ethics Committee of the Universidade Estadual de Feira de Santana (Protocol $n^{\circ}$ 077/2006), in accordance with Resolution $n^{\circ}$ $196 / 96$ on the ethical aspects passed by the Brazilian National Health Council [18]. The data of this research were used with the research coordinator's authorization.

\section{RE S U L T S}

The mean age of the 813 children evaluated was 31.65 months (standard deviation=4.06), ranging from 22.7 to 45.8 months. It was found that $96.3 \%(783 / 813)$ of these children were exclusively breastfed immediately after birth, but only $21.2 \%$ (172) were exclusively breastfed at 4 months of age, 
and $10.9 \%$ were breastfed up to 2 years of age. The most frequently consumed foods by the children were: porridge, margarine, vegetable oil, cooked rice, bread, sugar-sweetened fruit juice, banana-da-prata, sugar, and coffee.

As for the maternal BMI, 53.7\% (324/603) were well-nourished, 27.4\% (165) were overweight, $16.7 \%$ (101) were obese, and only $2.2 \%$ (3) were underweight. The other child and maternal characteristics are described in Table 1.

With regard to food consumption, the PCA identified four patterns, which explained $49.96 \%$ of the total data variance. Kaiser-Meyer-

Table 1. Characteristics of 813 children under 4 years old. Feira de Santana (BA), Brazil (2011).

\begin{tabular}{|c|c|c|}
\hline Variables & $\mathrm{n}$ & $\%$ \\
\hline \multicolumn{3}{|l|}{ Gender } \\
\hline Male & 420 & 51.7 \\
\hline Female & 393 & 48.3 \\
\hline \multicolumn{3}{|l|}{ Birth weight } \\
\hline$<2500 \mathrm{~g}$ & 35 & 4.3 \\
\hline$\geq 2500 \mathrm{~g}$ & 778 & 95.7 \\
\hline \multicolumn{3}{|l|}{ Child anthropometric status } \\
\hline Excessively thin & - & - \\
\hline Thin & 4 & 0.5 \\
\hline Well-nourished & 468 & 58.9 \\
\hline Overweight & 221 & 27.8 \\
\hline Obese & 73 & 9.2 \\
\hline Severely obese & 28 & 3.5 \\
\hline \multicolumn{3}{|l|}{ Bottle feeding } \\
\hline Yes & 512 & 63.0 \\
\hline No & 301 & 37.0 \\
\hline \multicolumn{3}{|l|}{ Consumption of foods in liquid form } \\
\hline Yes & 387 & 47.6 \\
\hline No & 426 & 52.4 \\
\hline \multicolumn{3}{|l|}{ Gestational age } \\
\hline Preterm & 29 & 3.6 \\
\hline term & 784 & 96.4 \\
\hline \multicolumn{3}{|l|}{ Maternal skin color } \\
\hline Black/brown & 667 & 82.0 \\
\hline White & 146 & 18.0 \\
\hline \multicolumn{3}{|l|}{ Maternal level of education } \\
\hline Elementary and Middle School (complete/incomplete)/Incomplete High School & 273 & 33.6 \\
\hline High School/Higher Education & 540 & 66.4 \\
\hline \multicolumn{3}{|l|}{ Work outside the home } \\
\hline Yes & 311 & 38.3 \\
\hline No & 502 & 61.7 \\
\hline \multicolumn{3}{|l|}{ Maternal income } \\
\hline$\leq 1$ minimum wage & 396 & 48.7 \\
\hline Over the minimum wage & 417 & 51.3 \\
\hline
\end{tabular}


Olkin value of 0.807 indicated the applicability of the factor analysis; the Bartlett's test of sphericity was significant ( $p$-value $\leq 0.001$ ), indicating correlation between the variables.

The dietary pattern 1 was characterized by a predominance of milk and other dairy products, vegetables and tubers, cereals, legumes, fruits, and fish. In dietary pattern 2, there was a predominance of deep-fried or baked snacks, soft drinks/artificial fruit juices, sweets, oils and fats, and coffee/tea. Dietary pattern 3 was characterized by the predominance of encased meats, fast foods, ketchup/mayonnaise, and eggs. In dietary pattern 4 , there was a predominance of chicken and red meats (Table 2)

The bivariate analyses showed that obesity was associated with: adequate birth weight $(P R=2.35)$, higher maternal income $(P R=1.30)$, maternal overweight/obesity $(P R=1.82)$, interruption of breastfeeding ( $P R=1.53)$, not weaning at 2 years of age ( $P R=1.54)$, and bottle feeding ( $P R=1.47$ ) (Table 3).

Obesity was not associated with any of the tertiles of dietary pattern (four) adherence in the crude (unadjusted) analysis (Table 4).

In the multivariate analysis, there was a statistically significant association between obesity and high adherence to dietary pattern $3(\mathrm{OR}=1.92)$ after adjustment for potential confounders (Table 5).

\section{DISCUSSION}

In the present study, there was a higher prevalence of obesity (12.7\%) and lower prevalence of thinness $(0.5 \%)$ among children younger than four years old. The increasing prevalence of obesity and decreasing prevalence

Table 2. Factor loading ${ }^{a}$ of the four dietary patterns identified among children under 4 years old. Feira de Santana (BA), Brazil (2011).

\begin{tabular}{lcccc}
\hline \multirow{2}{*}{ Foods/food groups } & \multicolumn{2}{c}{ Dietary patterns } \\
\cline { 2 - 5 } Milk and other dairy products & $1^{\mathbf{b}}$ & $2^{\mathrm{c}}$ & $3^{\mathrm{d}}$ & -0.007 \\
Ketchup/mayonnaise & 0.465 & -0.197 & 0.324 & 0.234 \\
Encased meats & 0.123 & 0.100 & 0.637 & -0.092 \\
Fast-food & 0.068 & 0.139 & 0.774 & -0.017 \\
Red meats & 0.286 & 0.051 & 0.682 & 0.637 \\
Vegetables and tubers & 0.194 & -0.198 & 0.300 & -0.048 \\
Cereals & 0.798 & 0.050 & 0.141 & -0.090 \\
Legumes & 0.570 & 0.527 & 0.150 & 0.303 \\
Fruits & 0.572 & 0.099 & 0.149 & -0.015 \\
Eggs & 0.711 & 0.254 & 0.124 & -0.018 \\
Chicken & 0.350 & 0.018 & 0.495 & 0.670 \\
Fish & -0.017 & -0.040 & -0.099 & 0.208 \\
Deep-fried or baked snacks & 0.403 & -0.135 & 0.203 & -0.008 \\
Soft drinks/artificial fruit juices & 0.018 & 0.641 & 0.055 & 0.037 \\
Sweets & 0.241 & 0.485 & 0.187 & 0.496 \\
Oils and fats & -0.069 & 0.610 & 0.028 & -0.412 \\
Coffee and tea & -0.115 & 0.539 & 0.106 & -0.234 \\
\hline
\end{tabular}

Note: a Factor loading $\geq 0.3$ or $\leq-0.3$; bietary pattern 1 (milk and other dairy products, vegetables and tubers, cereals, legumes, fruits, and fish); ' Dietary pattern 2 (deep-fried or baked snacks, soft drinks/artificial fruit juices, sweets, oils and fats, candies, and coffee/tea); ${ }^{\mathbf{d} D i e t a r y}$ pattern 3 (encased meats, fast-food, ketchup/mayonnaise, and eggs); 'Dietary pattern 4 (chicken and red meats). 
Table 3. Prevalence of obesity, Prevalence Ratios (PR), and 95\% Confidence Intervals ( $95 \% \mathrm{CI}$ ), according to child and maternal covariables of 813 children under 4 years of age. Feira de Santana (BA), Brazil (2011).

\begin{tabular}{|c|c|c|c|c|c|}
\hline Covariables & $\mathrm{N}$ & $\mathrm{n}$ & $\%$ & PR & $95 \%$ IC \\
\hline \multicolumn{6}{|l|}{ Birth weight } \\
\hline$<2500 \mathrm{~g}$ & 26 & 2 & 7.7 & 1.00 & - \\
\hline$\geq 2500 \mathrm{~g}$ & 547 & 99 & 18.1 & 2.35 & $1.97-2.81^{*}$ \\
\hline \multicolumn{6}{|l|}{ Maternal income } \\
\hline$\leq 1$ minimum wage & 287 & 44 & 15.3 & 1.00 & - \\
\hline Over the minimum wage & 286 & 57 & 19.9 & 1.30 & $1.03-1.64^{*}$ \\
\hline \multicolumn{6}{|l|}{ Maternal overweight/obesity } \\
\hline Yes & 176 & 42 & 23.9 & 1.82 & $1.40-2.36^{*}$ \\
\hline No & 251 & 33 & 13.1 & 1.00 & - \\
\hline \multicolumn{6}{|c|}{ Interruption of EBF at 4 months of age } \\
\hline Yes & 445 & 85 & 19.1 & 1.53 & $1.26-1.85^{*}$ \\
\hline No & 128 & 16 & 12.5 & 1.00 & - \\
\hline \multicolumn{6}{|l|}{ Weaning at 2 years of age } \\
\hline Yes & 67 & 8 & 11.9 & 1.00 & - \\
\hline No & 506 & 93 & 18.4 & 1.54 & $1.28-1.85^{*}$ \\
\hline \multicolumn{6}{|l|}{ Bottle feeding } \\
\hline Yes & 353 & 71 & 20.1 & 1.47 & $1.20-1.82^{*}$ \\
\hline No & 220 & 30 & 13.6 & 1.00 & - \\
\hline
\end{tabular}

Note: "The associated values were statically significancy.

EBF: Exclusive Breastfeeding.

of malnutrition have been reported by other researchers in recent decades in Brazil [19], a fact that characterizes nutrition transition. Changes in eating habits with increased consumption of high-calorie foods may help explain this phenomenon.

The dietary patterns identified in the present study are similar to those reported by D'Innocenzo et al. [5] in the city of Salvador (BA).

The dietary patterns 2 and 3 identified in the present study show a global trend that has been observed over the last three decades, which reflects contemporary living habits, including preference for industrialized foods and increased caloric intake $[20,21]$. These two patterns were characterized by foods high in fat and sugars. Nobre et al. [9] reported similar findings in a study involving preschoolers in the city of Diamantina (MG). These authors identified dietary patterns denominated "snacks" and "unhealthy". Similarly, D'Innocenzo et al. [6] found a dietary pattern characterized by fried foods, packaged snacks, soft drinks/artificial fruit juices, and another one characterized by encased meats, eggs, and red meats.

In the present study, there was a positive association between obesity and high adherence to dietary pattern 3 (encased meats, fast-food. ketchup/mayonnaise and eggs). Increased energy intake and decreased fiber intake are major factors contributing to obesity [22]. These dietary habits can be modified through intervention measures on healthy eating awareness $[22,23]$.

However, the present study showed some limitations such as the method used to obtain and analyze food consumption. Although the FFQ is the commonly used method to estimate individuals' usual frequency of food consumption, it has some limitations, such as it depends mostly on the memory of the subject 
Table 4. Prevalence of obesity, Prevalence Ratios (PR), and 95\% Confidence Intervals ( $95 \% \mathrm{Cl})$, according to the dietary patterns of 813 children under 4 years old. Feira de Santana (BA), Brazil (2011).

\begin{tabular}{|c|c|c|c|c|c|}
\hline \multirow{2}{*}{ Dietary pattern/Tertiles } & \multicolumn{5}{|c|}{ Obesity } \\
\hline & N & $\mathrm{n}$ & $\%$ & PR & $95 \% \mathrm{Cl}$ \\
\hline \multicolumn{6}{|l|}{ Dietary pattern $1^{\text {a }}$} \\
\hline T1 $(-2.74-<-0.43)$ & 265 & 24 & 9.1 & 1.00 & - \\
\hline T2 $(-0.43-<0.21)$ & 260 & 37 & 14.2 & 1.57 & $0.97-2.55$ \\
\hline T3 (0.21-4.73) & 266 & 38 & 14.3 & 1.58 & $0.97-2.55$ \\
\hline \multicolumn{6}{|l|}{ Dietary pattern $2^{\mathbf{b}}$} \\
\hline T1 $(-2.80-<-0.54)$ & 261 & 41 & 15.7 & 1.00 & - \\
\hline T2 $(-0.54-<0.37)$ & 266 & 29 & 10.9 & 0.69 & $0.45-1.08$ \\
\hline T3 $(0.37-5.10)$ & 264 & 29 & 11.0 & 0.70 & $0.45-1.09$ \\
\hline \multicolumn{6}{|l|}{ Dietary pattern $3^{c}$} \\
\hline T1 $(-1.89-<-0.43)$ & 252 & 31 & 12.3 & 1.00 & - \\
\hline T2 $(-0.43-<0.03)$ & 276 & 41 & 14.9 & 1.21 & $0.78-1.86$ \\
\hline T3 (0.03-7.18) & 263 & 27 & 10.3 & 0.83 & $0.51-1.36$ \\
\hline \multicolumn{6}{|l|}{ Dietary pattern $4^{\mathrm{d}}$} \\
\hline T1 $(-2.44-<-0.56)$ & 278 & 41 & 14.7 & 1.00 & - \\
\hline T2 $(-0.56-<0.50)$ & 252 & 32 & 12.7 & 0.86 & $0.56-1.32$ \\
\hline T3 (0.50-4.33) & 261 & 26 & 10.0 & 0.67 & $0.43-1.07$ \\
\hline
\end{tabular}

Note: aDietary pattern 1 (milk and other dairy products, vegetables and tubers, cereals, legumes, fruits, and fish); ${ }^{\mathbf{b}}$ Dietary pattern 2 (deep-fried or baked snacks, soft drinks/artificial fruit juices, sweets, oils and fats, candies, and coffee/tea); 'Dietary pattern 3 (encased meats, fast-food, ketchup/mayonnaise, and eggs); dDietary pattern 4 (chicken and red meats).

being interviewed, presence of interview-related difficulties, and the fact it does not allow precise estimation of portion size of foods consumed. Moreover, the factor analysis carried out to identify the dietary patterns involved making arbitrary decisions regarding the number of factors that were not retained, the choice of orthogonal rotation, the determination of factor loading significance, and the identification and interpretation of the dietary patterns.

On the other hand, it is worth emphasizing the value and importance of the present study, which is a cross-sectional, population-based study nested within a cohort study that was carried out using factor analysis to identify patterns of food consumption, a more reliable method than the consumption of nutrients, in order to evaluate the eating habits of a specific group.

The internal consistency of the identified dietary patterns reinforce the pre-established scientific knowledge that the consumption of processed and high-calorie foods, such as encased meats, fast foods, ketchup, and eggs is a predictor of obesity in childhood $[24,25]$.

Aiming to encourage the adoption of healthy eating habits among people, at the individual and population levels, and to prevent childhood overweight and obesity, public policies and food education programs are necessary [12], especially in health units and public and private schools to provide educators, parents, and caregivers with information about the nutritional quality of foods and the increased risk of obesity due to the consumption of some industrialized and high-calorie foods [7].

It is also necessary to warn the population that the prevention of obesity in adulthood starts at as early as the day a child is born with breastfeeding and healthy eating habits in the first years of life so that they can make informed 
Table 5. Association between dietary patterns and obesity among children under 4 years old, controlling for confounding with logistic regression. Feira de Santana (BA), Brazil (2011).

\begin{tabular}{|c|c|c|c|}
\hline Covariables & $p$ & OR & $95 \% \mathrm{Cl}$ \\
\hline \multicolumn{4}{|l|}{ Dietary pattern $1^{\mathrm{a}}$} \\
\hline T1 $(-2.74-<-0.43)$ & 0.257 & 1.00 & - \\
\hline T2 $(-0.43-<0.21)$ & 0.437 & 0.76 & $0.38-1.52$ \\
\hline T3 (0.21-4.73) & 0.334 & 1.35 & $0.73-2.50$ \\
\hline \multicolumn{4}{|l|}{ Dietary pattern $2^{\mathbf{b}}$} \\
\hline $\mathrm{T} 1(-2.80-<-0.54)$ & 0.166 & 1.00 & - \\
\hline T2 $(-0.54-<0.37)$ & 0.087 & 1.84 & $0.92-3.72$ \\
\hline T3 (0.37-5.10) & 0.767 & 1.11 & $0.56-2.21$ \\
\hline \multicolumn{4}{|l|}{ Dietary pattern $3^{\mathbf{c}}$} \\
\hline T1 $(-1.89-<-0.43)$ & 0.141 & 1.00 & - \\
\hline $\mathrm{T} 2(-0.43-<0.03)$ & 0.239 & 1.50 & $0.76-2.96$ \\
\hline T3 (0.03-7.18) & 0.048 & 1.92 & $1.01-3.66^{*}$ \\
\hline \multicolumn{4}{|l|}{ Dietary pattern $4^{\mathbf{d}}$} \\
\hline $\mathrm{T} 1(-2.44-<-0.56)$ & 0.223 & 1.00 & - \\
\hline T2 $(-0.56-<0.50)$ & 0.146 & 1.79 & $0.82-3.92$ \\
\hline T3 (0.50-4.33) & 0.100 & 1.79 & $0.90-3.56$ \\
\hline
\end{tabular}

Note: *The associated values were statistically significant; a Dietary pattern 1 (milk and other dairy products, vegetables and tubers, cereals, legumes. fruits, and fish), Odds Ratios (OR) adjusted for birth weight, exclusive breastfeeding, consumption of foods in liquid form, maternal level of education, maternal income, maternal overweight, maternal work, dietary pattern 2, dietary pattern 3, and dietary pattern 4; ${ }^{\mathbf{b}}$ Dietary pattern 2 (deep-fried or baked snacks, soft drinks/artificial fruit juices, sweets, oils and fats, candies, and coffee/tea), OR adjusted for birth weight, exclusive breastfeeding, consumption of foods in liquid form, maternal level of education, maternal income, maternal overweight, maternal work, dietary pattern 1, dietary pattern 3, and dietary pattern 4; 'Dietary pattern 3 (encased meats, fast-food, ketchup/mayonnaise, and eggs), OR adjusted for birth weight, exclusive breastfeeding, consumption of foods in liquid form, maternal level of education, maternal income,

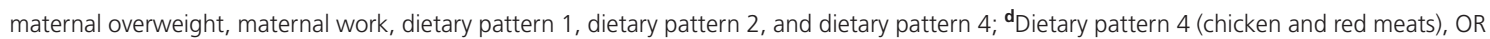
adjusted for birth weight, exclusive breastfeeding, consumption of foods in liquid form, maternal level of education, maternal income, maternal overweight, maternal work, dietary pattern 1, dietary pattern 2, and dietary pattern 3.

95\% Cl: 95\% Confidence Intervals.

decisions due to globalization and changes in social structures that contribute the adoption of harmful eating habits with increased consumption of industrialized and energy-dense foods [5].

\section{CONTRIBUTIONS}

KEPS GOMES contributed to the conception and design of this study, data analysis and interpretation, and revision and approval of the final version. MCO COSTA contributed to the revision and approval of the final version. TO VIEIRA contributed to the revision and approval of the final version. SMA MATOS contributed to data analysis and interpretation and to the revision and approval of the final version. GO VIEIRA contributed to the conception and design of this study and to the revision and approval of the final version.

\section{REFERE NCES}

1. Baker JL, Farpour-Lambert NJ, Nowicka P, Pietrobelli A, Weiss R. Evaluation of the overweight/obese child - practical tips for the primary health care provider: Recommendations from the childhood obesity task force of the European Association for the Study of Obesity. Obes Facts. 2010;3(2):131-7. https://doi.org/10.1159/000295112

2. Instituto Brasileiro de Geografia e Estatística. Pesquisa de orçamentos familiares 2008-2009: antropometria e estado nutricional de crianças, 
adolescentes e adultos no Brasil. Rio de Janeiro: IBGE, 2010 [acesso 2014 jan 20]. Disponível em: http://www.ibge.gov.br/home/estatistica/ populacao/condicaodevida/pof/2008_2009_ encaa/default.shtm

3. Lo K, Cheung C, Lee A, Tam WWS, Keung V. Associations between parental feeding styles and childhood eating habits: A survey of Hong Kong pre-school children. PLoS One. 2015;10(4). https://doi.org/10.1371/journal.pone.0124753

4. Carvalho CA, Fonsêca PCA, Nobre LN, Priore SE, Franceschini SCC. Metodologias de identificação de padrões alimentares a posteriori em crianças brasileiras: revisão sistemática. Ciênc Saúde Coletiva. 2016;21(1):143-54. https://doi.org/10.1590/14 13-81232015211.18962014

5. D’Innocenzo S, Marchioni DML, Prado MS, Matos SMA, Pereira SRS, Barros AP, et al. Condições socioeconômicas e padrões alimentares de crianças de 4 a 11 anos: estudo SCAALA Salvador/Bahia. Rev Bras Saúde Matern Infant. 2011;11(1):41-9. https://doi.org/10.1590/s151938292011000100005

6. D'Innocenzo S, Matos SMA, Prado MS, Santos CAST, Assis AMO, Cruz AA, et al. Padrão alimentar, asma e sibilo atópico e não atópico em crianças e adolescentes: estudo SCAALA, Salvador, Bahia, Brasil. Cad Saúde Pública. 2014;30(9):1849-60. https://doi.org/10.1590/0102-311X00165513

7. Souza RLV, Madruga SW, Gigante DP, Santos IS, Barros AJD, Assunção MCF. Padrões alimentares e fatores associados entre crianças de um a seis anos de um município do Sul do Brasil. Cad Saúde Pública. 2013;29(12):2416-26. https://doi. org/10.1590/0102-311X00156412

8. World Health Organization. Preparation and use of food based dietary guidelines. Geneva: WHO: 1998 [cited 2015 Dec 15]. Available from: https://www.who.int/nutrition/publications/ nutrientrequirements $\mathrm{WHO}$ _TRS_880/en

9. Nobre LN, Lamounier JA, Franceschini SCC. Preschool children dietary patterns and associated factors. J Pediatr. 2012;88(2):129-36. https://doi. org/10.2223/JPED.2169

10. Jesus GM, Vieira GO, Vieira TO, Martins CC, Mendes CMC, Castelão ES. Determinants of overweight in children under 4 years of age. J Pediatr. 2010;86(4):311-16. https://doi.org/10.15 90/S0021-75572010000400011

11. Vieira GO, Martins CC, Vieira TO, Oliveira NF, Silva LR. Factors predicting early discontinuation of exclusive breastfeeding in the first month of life. J Pediatr. 2010;86(5):441-4. https://doi. org/10.1590/S0021-75572010000500015
12. World Health Organization. Growth reference data for 0-5 years. Geneva: WHO 2007 [cited 2015 Jan 30]. Available from: http://www.who. int/growthref/en/

13. World Health Organization Working Group on Infant Growth. An evaluation of infant growth: The use and interpretation of anthropometry in infants. Bull World Health Organ. 1995 [cited 2015 Jan 30];73(2):165-74. Available from: http://www. ncbi.nlm.nih.gov/pmc/articles/PMC2486761/pdf/ bullwho00406-0033.pdf

14. Olinto MTA. Padrões alimentares: análise de componentes principais. In: Kac G, Sichieri R, Gigante DP, organizadores. Epidemiologia nutricional. Rio de Janeiro: Fiocruz; 2007. p.213-25.

15. Hair Jr JF, Black WC, Babin BJ, Anderson RE, Tatham RL. Análise multivariada de dados. $6^{a}$ ed. Porto Alegre: Bookman; 2009.

16. Statistical Package for Social Sciences. Base 9.0 for Windows: User's guide. Chicago (IL): SPSS; 2000

17. R Development Core Team. R: A language and environment for statistical computing. Version 2.12.0. Viena: $R$ Foundation for Statistical Computing; 2010 [cited 2010 Dec 15]. Available from: http://www.r-project.org

18. Ministério da Saúde (Brasil). Resolução nº 196 de 10 de outubro de 1996. Diário Oficial [da] República do Brasil. Brasília: Ministério da Saúde; 1996 [acesso 2009 out 10]. Disponível em: http:// conselho.saude.gov.br/web_comissoes/conep/ aquivos/resolucoes/23_out_versao_final_196_ ENCEP2012.pdf

19. Sotero AM, Cabral PC, Silva GAP. Socioeconomic, cultural and demographic maternal factors associated with dietary patterns of infants. Rev Paul Pediatr. 2015;33(4):445-52. https://doi.org/10. 1016/j.rpped.2015.03.006

20. Suné FR, Dias-da-Costa JS, Olinto MTA, Patussi MP. Prevalência e fatores associados para sobrepeso e obesidade em escolares de uma cidade no Sul do Brasil. Cad Saúde Pública. 2007;23(6):1361-71. https://doi.org/10.1590/S01 02-311X2007000600011

21. Oliveira AMA, Cerqueira EMM, Souza JS, Oliveira AC. Sobrepeso e obesidade infantil: influência de fatores biológicos e ambientais em Feira de Santana, BA. Arq Bras Endocrinol Metab. 2003;47(2):144-50. https://doi.org/10.1590/S000 4-273020030000200006

22. Levy DT, Friend KP. Simulation modeling of policies directed at youth sugar-sweetned beverage consumption. Am J Community Psychol. 2013;51(1-2):299-313. https://doi.org/10.1007/s10 464-012-9535-5 
23. Shiu LK, Loke WM, Vijaya K, Sandhu NK. Nurturing healthy dietary habits among children and youth in Singapore. Asia Pac J. 2012 [cited 2014 Dec 20];21(1):144-50. Available from: http://apjcn. nhri.org.tw/server/APJCN/21/1/144.pdf

24. Ford CN, Slining MM, Popkin BM. Trends in dietary intake among US 2-to 6-year-old children, 1989-2008. J Acad Nutr Diet. 2013;113(1):35-42. https://doi/10.1016/j.jand.2012.08.022
25. Zaghloul S, Al-Hooti SN, Al-Hamad N, Al-Zenki $\mathrm{S}$, Alomirah $\mathrm{H}$, Alavan I, et al. Evidence for nutrition transition in Kuwait: Over-consumption of macronutrients and obesity. Public Health Nutr. 2013;16(4):596-607. https://doi.org/10.1017/S136 8980012003941

Received: September 20, 2016

Final version: May 2, 2017

Approved: June 19, 2017 